УДК 821.163.3-2.09 Чашуле К. https://doi.org/10.18485/godisnjak.2021.16.6

Звонко Танески*

Универзитет Комениус, Братислава

Филозофски факултет

Катедра за словенски филологии
Оригинални научни рад

Примљен: 30. 09. 2021.

Прихваћен: 05. 11. 2021.

\title{
ДРАМИТЕ ОД МАКЕДОНСКИОТ ПИСАТЕЛ КОЛЕ ЧАШУЛЕ ВО СЛОВАЧКАТА КУЛТУРНА РЕЦЕПЦИЈА
}

\begin{abstract}
Статијата нуди комплектен приказ за присуството на драмското книжевно творештво од познатиот македонски автор Коле Чашуле во Република Словачка и тоа по повод јубилејот 100 години од неговото раѓање на кој со пиетет си споменуваме во тековнава 2021 година. Авторот на текстот изврши архивско истражување од кое читателите можат да добијат потполна слика за целокупната рецепција на творештвото на овој репрезентативен македонски писател во словачкиот културен простор (преводи во периодиката и книжни изданија). Наедно прави и подетална анализа на драмата Игра или сочијалистичка Ева, која се појави во превод на словачки јазик речиси пред половина век.
\end{abstract}

Клучни зборови: Коле Чашуле, македонска книжевност, словачка рецепција, превод.

Оваа 2021 година одбележуваме симболични 100 години од раѓањето на големиот македонски писател Коле Чашуле (1921 - 2009). По тој повод, со понудениов текст решивме да дадеме скромен придонес во прославувањето на таквиот јубилеј, а, наедно, уште еднаш да го свртиме и вниманието на пошироката научна јавност со тоа што ќе ја претставиме

*zvonko.taneski@uniba.sk 
за прв пат, во домашни и во меѓународни рамки, комплетната досегашна рецепција на неговото драмско творештво во Република Словачка со посебен осврт на неговото драмско дело Игра или социјалистичка Ева, која во книжен превод на словачки јазик се објави во веќе далечната 1967 година (С̆ašule 1967: 52).

Токму драмата Игра или соиијалистичка Ева (оригиналното издание е од 1961 година) од познатиот македонски драматург, а воедно и дипломат, Коле Чашуле е, впрочем, првата цела преведена македонска драма во Република Словачка. Преводот е дело на словачкиот лингвист и славист Емил Хорак, кој притоа малку го доадаптирал насловот во Hra na manželstvo (во слободен превод - Глумење брак, 1967), што од денешна (читај: несоцијалистичка!) перспектива, несомнено, претставува посреќно и попримамливо решение. Недвосмислен е фактот дека Чашуле е еден од најзначајните македонски драматурзи, кои уште со својот првенец $E \partial н а$ вечер (1948), а особено со Вејка на ветрот (1957) ја потврди својата суштинска улога во повоениот развој на македонската драмска литература. Бездруго, тоа дело за многумина театролози го означува и почетокот на еманципаторскиот процес во современата драматургија во Македонија бидејќи прави творечки пресврт или приклонување кон модерните постапки во драмската текстовна структура.

Набрзо потоа, во словачкиот културен ареал повторно ќе се осведочи името на Коле Чашуле како еминентен драмски творец со оглед на тоа што во 1973 година Македонскиот народен театар од Скопје ќе гостува во Словачка со неговата драма Црнила, која била изведена во театарот Нова сцена во Братислава, според нејзината оригинална верзија, на македонски јазик. За настанот тогаш благовремено информирале во форма на кратки рецензии и стручни медиумски одгласи и три познати домашни (државни) дневни весници. ${ }^{1}$ Автор на последниот регистриран одглас е Андреј Врбацки (1908-1974), Словак по потекло од Војводина, етаблиран новинар и продуктивен преведувач и афирматор на книжевностите од поранешна Југославија (најчесто, сепак, на српската и на хрватската, а делумно и на бугарската книжевност), кој меѓу другото е и автор на еден од сосема првите новинарски написи за целокупниот развој на македонската книжевност објавени на словачки јазик и во Р. Словачка по Втората светска војна, односно по 1945 година (Види на пример: Vrbacký 1948: 4).

Успехот на наведената сценска изведба на драмата Црнила од К. Чашуле во Братислава во 1973 година го отворил набрзо и прашањето за нејзиниот превод на словачки јазик. Повторно со несебична помош на

${ }^{1}$ Види повеќе: Staček 1973: 6; Vrbacký 1973: 5 
Словаците од Војводина, целиот превод на драмата на словачки јазик ќе биде објавен десетина година подоцна во Нови Сад (Р. Србија), конкретно во 1982 година, како составен дел на книжната едиција на тамошното словачко списание Нови живот (С̆ašule 1982). Преводот на таа драма (официјално издаден од страна на издавачката куќа Обзор од Нови Сад) е овој пат дело на познатиот словачки преведувач, поет и дипломат Франтишек Липка (1946), чиј преведувачки опус од јужнословенските книжевности на словачки јазик во осумдесеттите и во деведесеттите години на дваесеттиот век е навистина вреден за почит. Делото Црнила (Драма во четири чина) од Коле Чашуле е во истата година објавувано и во четири продолженија на страниците на списанието Нови живот. ${ }^{2}$ За творечкиот профил на Коле Чашуле, како и за самото издание пишува прецизни белешки во таа прилика и преведувачот Ф. Липка (Lipka 1982: 64; Lipka 1982a: 67-85), а исто така и Виќазослав Хроњец (1944), кој е исто така исклучителен, буден и неуморен проследувач и на делата од македонската книжевност во словачката периодика и во словачките издавачки куќи во Војводина (Hronec 1982: 416).

Мошне успешниот прием на Коле Чашуле меѓу војводинските Словаци во почетокот на осумдесеттите години на минатиот век ќе придонесе и за реализацијата на еден прилично несекојдневен настан три години подоцна, кога на страниците на споменатото списание Нови живот (кое излегува сѐ до денес и сѐ уште многу професионално отстапува простор и за преводи и статии поврзани со македонската книжевност) ќе биде објавена и комплетната реч, т. е. воведна беседа на Коле Чашуле (во тоа време - претседател на Претседателството на Сојузот на писателите на Југославија) на Деветтиот конгрес на Сојузот на писателите на Југославија кој се одржал во Нови Сад на 17 април 1985 година. Преводот на беседата е извршен од страна на Људмила Демакова и Мирослав Демак, а објавена е во петтиот број на списанието во 1985 година. ${ }^{3}$ Подоцна, преведувачот Мирослав Демак ќе го продлабочи интересот и за други писателски имиња од корпусот на современата македонска книжевност, кои постепено ќе ги претставува на словачки јазик во културниот простор на денешна Р. Словачка.

Кон крајот на осумдесеттите години името на Коле Чашуле ќе се појави и во облик на посебна речничка статија во две важни словачки академски енциклопедии и тоа Ениџилопедија на светски писатели (1987)

\footnotetext{
${ }^{2}$ Види подетално: С̆ašule 1982a: 67-85; Čašule 1982b: 168-180; Čašule 1982c: 287-298; Čašule 1982d: 399-415.

${ }^{3}$ Види подетално: Čašule 1985: 343-358.
} 
(Čašule 1987: 120-121) и Енциклопедија на книжевни дела (1989) (Čašule 1989: 864). Автори на речничката статија во првата наведена енциклопедија се Бранислав Хома и Златко Клатик, двајцата, исто така, добри познавачи на словачко-јужнословенските книжевни врски, како и вредни преведувачи на дела од словенскиот југ на словачки јазик. Автор, пак, на другата речничка статија во втората наведена енциклопедија, посветена на делото Црнила од Коле Чашуле, е словачкиот академик Јан Јанкович за чии заслуги во полето на афирмацијата на македонската книжевност посветено пишувавме пред неколку години (Види: Танески 2018: 58-75). Коле Чашуле е најпосле застапен со речничка статија и во поновата репрезентативна словачка енциклопедија Белиана (во 2003 година) ${ }^{4}$, која во повеќе томови периодично ја издаваше Енциклопедискиот институт при Словачката академија на науките во Братислава. Авторка на речничката статија е Ивета Лапуникова, а во улога на редактор на сите речнички статии во енциклопедијата Белиана посветени на македонската книжевност се јавува д-р Звонко Танески од Катедрата за словенски филологии на Филозофскиот факултет при Универзитетот „Комениус” во Братислава.

Сепак, за драмското творештво на Коле Чашуле во словачкиот културен контекст понудува опширни аналитички видувања досега единствено д-р Звонко Танески, кој генерално пишува за драмското творештво во словачко-македонските културни врски од втората половина на дваесеттиот век па сѐ до денес ${ }^{5}$, а сетне е и автор на една поопширна интерпретациска согледба за драмата Игра или сочијалистичка Ева која, како што наведовме погоре, е првата преведена македонска драма на словачки јазик воопшто ${ }^{6}$. Во согласност со потребите на зацртаната тема за што покомлексно претставување на рецепцијата на драмското творештво на Чашуле во Словачка, се одлучивме на крајот од текстов да презентираме и дел од заклучоците на предметната критичка согледба за таа конкретна драма од К. Чашуле погледната првенствено преку теорискиот апарат на словачката книжевно-научна призма на толкување. Имено, читајќи го Чашуле на едно парадигматско рамниште, всушност, и порано и сега негува(в)ме впечаток дека тој, небаре, не може да се ослободи од тезата дека човекот постепено ги губи емоциите во својот живот и се приспособ-

\footnotetext{
${ }^{4}$ Види повеќе: С̆ašule 2003: 121.

${ }^{5}$ Стидијата е објавена посебно во специјализираното научно писание Slovenské divadlo при Словачката академија на науките во 2009 година, а истата година е поместена и како составен дел од научната монографија: Taneski 2009: 131-142. За најновата рецепција на македонското драмско творештво во Словачка е пожелно да се погледне уште и студијата: Taneski 2020: 176-184.

${ }^{6}$ Види подетални информации во: Танески 2007: 67-68; Танески 2021: 175-179.
} 
ува кон рутината и кон копнежот, преку кој расте и се доразвива неговиот живот. Голем и непресушен извор на теми за драмска реализација, за Чашуле, е самиот живот и неговите протагонисти - обичните луѓе. Авторот не остава да му избегаат од контрола особеностите на обичниот човек, какви што се, на пример: љубомората, лакомоста, создавањето интриги, збогатувањето и сл. Чашуле се претставува и како одличен раскажувач со смисла за јазичен хумор. Воедно си присвојува терминологија, што ја извлекува од политичките, новинарските и научните клишеа. Шеговито и со голема мера на антиутопија алудира на тешко совладливите проблеми, кои долго нѐ депримираат во општеството.

Игра или соичјалистичка Ева не спаѓа во редот на најдобрите реализации на овој автор, но сепак, ги истакнува и ги одразува барем карактеристичните црти на средината во која се појавила. Игра е, бездруго, весела претстава од современиот секојдневен живот во три дејства (седум слики) и претставува репер за театарска пиеса, што би можела да има континуиран успех на „штиците што значат живот”. Во „играта” настапуваат мал број ликови. Двајцата главни (Мирко, Ирена) и четирите споредни (келнерот, адвокатот, младичот, келнерката), кои во дејството влегуваат единствено со функција на секундарна ролја што само треба да ја дополни авторската поента. Карактерите на ликовите се само скицирани, па затоа широкиот спектар на интервенции може да го искористи токму режисерот или драматургот во сценската верзија. Не е додржано ниту единството на дејството, местото и времето во драмата. Конфликтот и местото, сепак, не се менуваат, но единството на времето го нарушуваат поединечните дејства. Играта се оджува во гарсониера, во мотел, во салонска просторија на стан, во адвокатска канцеларија и во слаткарница. Сите слики се, значи, во ентериер што авторот совршено го опишал - дури од грамофонот, па сѐ до бојата на завесите. Токму таквите финеси ѝ даваат модерен штимунг на целата драма. Карактерот на ликот можеме да го толкуваме различно, при што погледот и просторот ги имаме зафиксирано и однапред определено. Авторот ги презентира ентериерите и внатрешната атмосфера како модел за завршена целина, од кој може да се добие поголема сила за почеток на конфликтот. Тоа е така затоа што, пред сѐ, природата и нејзината отвореност во нас мотивира ослободеност. Неговите мали соби и простории ги толкуваме низ херменевтичкиот клуч дека главниот лик нема каде да оди и мора да остане со своите проблеми. Затоа, таквиот клуч претставува одличен реквизит за градација. Природата се споменува во еден случај и тоа при описот на временската прогноза, кога дождот создава замрачена атмосфера, која во претпоследната слика и се очекува. 
Посебна одлика на драмата е „исклучивоста” на дијалогот. Сценскиот разговор во ова дело се наоѓa во помал обем. Играта се структурира најмногу со монолози. Небаре е тоа ненапишана авторска потврда или тврдење дека човекот е монолошко суштество. Меѓутоа, токму тие монолози му даваат можност на читателот односно на гледачот да се подзагледа во душата на ликот. Затоа, треба да се има предвид констатацијата дека секој може да го сфати карактерот на која било персона во претставата - на поинаков начин. Во секој случај, имаме впечаток дека авторот си мисли оти дијалозите не се потребни во предниот план на драмата, затоа што вистинските дијалози, според Чашуле, се оние помеѓу срцето и разумот. Таквиот принцип го прима позитивно, напати дури и малку патетично. Тој дијалог е спас за човекот. Затоа, играта има две скриени линии. Едната ја содржи љубовта меѓу двајца луѓе со заплет, а втората линија е политичкиот проблем (социјалистичкото милје). Таквиот проблем може да се интерпретира различно, но како и да е, одбраната стратегија ја отвора можноста за согледување на повеќето мотиви претставени во драмата.

Драмата е иронична; посилната доза на иронија може да се почувствува во воведот. Саркастичните сегменти и самоиронијата побудуваат кај гледачот или кај читателот - потсмевање односно засмејување. Сѐ станува двосмислено при што доаѓа до израз силата на избраните зборови. Или подобро, играта со зборовите и мислата на нивниот адресат. Како пример, може да послужи синтагмата obchodný vzt'ah (трговска врска), каде што под „трговски” се мисли нешто строго, безчувствително, по договор, а под ,врска” се подразбира исполнетоста со љубов и со емоции. Впрочем и слабата страна на драмата е, според наше убедување, мотивот на љубовта. Во прв ред, претпоставуваме како таа ќе се развива. Тоа е мошне претчувствително и прозрачно. Контрастот на љубовта како нешто силно и полно со емоции во заедништво со „трговијата”, што е полна со грубост, измами и интриги е неспоива, неодржителна. На моменти дури ни се наметнува и впечатокот дека самиот автор не издржал да ја истурка до крај оправданоста на наведениот контраст со што драмата завршува во форма на happy end. Tоа, секако, не е на штета на гледачот, затоа што во сценската изведба токму тој е и најважен. Имајќи го во заднина и општествениот колорит кон кој оваа драма инклинира, тоа е разбирливо и прифатливо. Затоа не треба да се решава прашањето дали мотивот на љубовта е видлив уште од почетокот. Иако е тоа, во извесни делови, наивно, за гледачот станува и останува до крај привлечно. Впрочем, и во таа смисла, „за Игра - или социјалистичка Ева критичките забелешки се однесуваат на недостатно развиените ликови, за сценското дејство кое останува недоискажано и 
сл., иако општиот заклучок би бил дека се работи за комичен текст кој заради актуелноста на проблемот што го зафаќа несомнено е текст што побудува интерес кај публиката" (Сталев 1996: 51). Играта, на крајот на краиштата, содржи и многу модерни терминолошки синегдохи на денешниот назив „корупција” (трговија, туѓи лаги, цигари и скап алкохол и сл.) што на нејзината тема ѝ придаваат на „ексклузивност”. Од горенаведеното може продуховено да се извлече, како апликација за нашиов контекст, и функционалната словачката пословица, која е видлива во целата драма: $Z a$ všetkým hl'adaj ženu! (буквално: Зад сѐ барај жена! односно контекстуално: За сѐ е виновна жената!).

Познататиот, но и непознатиот облик на интригата околу нас и во нас (и во бракот), а најпосле и во обликот на нашето човечко битие во денешниот свет претставува голема и неисцрпувачка тема на дискурсот на Чашуле. Оваа драма, низ симболична призма, ја отсликува техниката за тоа како човекот со помош на својот разум речиси совршено им подлегнува на комичните околности и на интригите, тогаш - кога во преден план се појавува борбата за подобар живот. Токму преку таквата техника неотповикливо се поврзуваат надежите на двајцата „фиктивни” сопружници: Мирко и Ирена. Станува збор за тоа дека човекот во борбата за подобар (читај: попрактичен!) живот (во драмата - да се добие поголем стан од фирмата) мора да го користи надежниот „рејтинг” на своето приспособување кон околностите што би требало да му бидат наклонети, а не ненаклонети, односно да распознае што е она што е од прагматичен интерес за животот на еден сопруг, а што не е, што ќе рече - уште посовршено да се приспособува! Кога во тоа не би успеал, веројатно самиот би се уништил. Сепак, и тогаш кога се зголемуваат можностите и кога расте материјалната благодат, луѓето не се секогаш посреќни, како што самите очекувале. Коле Чашуле пропатувал низ целиот свет, но не забележал дека со растот на организираноста на животот и благосостојабата расте и насмевката на лицата од луѓето. Попрво, може да се рече дека е тоа - обратно. Видел многу загрижени луѓе без искри на љубов во уморените очи. Не може да се оттргне од чувството дека човекот, пред cè, jа потиснува емоционалната страна на својата личност (што е напати видливо и преку комиката)! Овој автор ја поврзува радоста од животот и со организираноста и со животната акција, како и со униформираноста и со широката посветеност. Но, неговите тежишта не се приклонуваат, според нас, на страната на организираноста и униформираноста - кој го претпоставува тоа, негува лоша претпоставка! Затоа ги примаме делата на Чашуле во поширок книжевен контекст како уметнички факт што 
е вреден за внимание и за почит. Затоа, Чашуле е и првиот современ македонски драматург кого словачката култура го прими како еден од поважните балкански творци на нашето време. Таа објективно и точно го подвлече фактот дека во македонската литература од поодамна стапил светскиот литературен процес, а и македонската литература во светскиот литературен процес. Неговата особено индивидуализирана уметничка експресија е во исто време и експресија за целиот книжевен свет, затоа што е втемелена во него.

Друга карактеристика на Играта пак, претставува и исклучивоста на традиционалниот (според навикнатоста) сценски „пингпонг”, на кој се навикнати актерите. Едниот кажува нешто, го подава топчето, другиот возвраќа. Во оваа игра доминираат монолозите, иако актерите се навикнати на дијалог, на играта на реплики, што претставува, во секој случај, надворешна мотивација. Експресивните слики и разговорниот речник веројатно, во ваквата тематска поставеност, не го изненадуваат гледачот. На Чашуле, за среќа, му успева да ја пододврзе етички разиграната неподносливост на своето послание со помош на малата доза на свеж хумор. Во неговите ликови срцето сака, а разумот зборува: ова не е можно! Разумот го отсликува искуството, а можно претставува и инстинкт за самодбрана на „бракот”. Раздорот меѓу чувствата и разумот е и извор на „инфаркти”. Токму и од тие причини, критиката може да најде во делата на овој автор различни индивидуални светови, што се распоредени вертикално. Поединечните претстави често не можат да се сместат во една поопшта претстава, затоа што ја надминуваат неа. Јазикот на едниот не може да го замени јазикот на другиот, ниту јазиците на мнозинството, кои се неповторливи, прецизни и, на свој начин, усовршени. Брачните игри и игрите со разводите се тесно поврзани и со денешните луѓе во капиталистичкиот свет (иако, парадоксално, ова е игра за социјалистичката Eва)! Затоа, оваа драма сведочи за тоа дека историцизмот и временската дистанца не ја потврдуваат секогаш потребата за ситуирање на авторот во еден временски теснец. Преку временската оддалеченост, на крајот на краиштата, се создаваат и предуслови за отстранување на дивергенциите што постојат меѓу животот и творештвото на авторот со оние што го забрануваат неговото паѓање во „социјалистичкиот” заборав. Така се доаѓа до постојаното и дефинитивно признание на „игрите” од Чашуле.

При вреднувањето на социјалистичката Ева треба да се ослободиме и од фетишизацијата на формата и не треба да дозволиме да нѐ подјарми дефинитивноста и тоталноста на традицијата во апологетската смисла на зборот. Светот на драмското дело е жив процес, надградба. Најпосле, 
претставува и негација и никогаш нема да се задоволи со постоечкото, според мотото: Ништо веќе не е толку свето (ниту бракот!) за да не може да биде почовечко и за чекор поблиско до креативниот понор (глумењето брак)! Затоа, во извесна смисла е симптоматично да се гледа на „социјалистичката" мисла на Чашуле со очите на негативното, дури и на деградирачкото словачко искуство од социјализмот. Единствено во неколку занемарливи моменти на „новопретставената преадаптација”, драмата би можела да упати на тенденцијата - да замисли паралела со реалноста на изградбата на социјалистичкото општество во педесеттите години на дваесеттиот век или поточно, со трагикомичните феномени во периодот на нормализацијата - онаква, каква што ја познаваме од словачката средина.

Чашуле им нуди незатворени приказни на своите читатели. Тој го гледа „универзалниот” човек (овде и сега) хармоничен во мигот на враќање кон ваквата вечна игра. Тогаш станува поемоционален и поправичен, затоа што денешното глумење брак има многу цели и сокрива многу тајни, така што од него можат да се истакнуваат различни страни на преден план. Некои истакнуваат дека живееме во век на „интригантска” револуција, други пак, во сооднос на Чашуле, - во ера на „институционално-комедијална" криза (бракот како можност за личен интерес). Но, Чашуле внесува во таквиот објектив и нешто убаво, привлечно, комично, без кое светот би бил некако поедноличен, посиромашен од „општествена” гледна точка. Не би биле тогаш целосно рафинирани социјалните, етичките и психолошките размери на егзистенцијата. Затоа, не треба да заборавиме да се прашаме самите сега и овде, во нашата реалност, дали проникнати со новиот копнеж за нови значења и форми; принудени да го бараме она новото во нашиот современ микрокосмос, создаваме традиција што утрешната генерација ќе ја прими и дали притоа ќе се надминат нашите бројни (биографски) ограничености? Не постојат завршени процеси: постојат добри, познати книжевни системи, впечатоци и вредности, поголеми или помали практични искуства и непрестајни напредувања без кои на животот и на креативноста би им недостасувале смисла и мотивација. Затоа, со право, сакаме да веруваме дека драмското творештво на Коле Чашуле ќе мотивира и ќе предизвика во иднина и нови прочити и критички вреднувања во Словачка во годините што следат пред нас на задоволство на сите љубители на добрата и универзално перспективна европска драма. 


\section{ЛИТЕРАТУРА}

Сталев 1996: Георги Сталев, Драматичарскиот профил на Коле Чашуле. Во: ОКО (Македонска ревија за литература), Скопје, бр. 19, мај 1996.

Танески 2007: Звонко Танески, Проиесот на надградба во „словачката игра" на Коле Чашуле. Во: Синтези, Скопје, бр. 7, стр. 67-68 (Rec.: Hra na manželstvo / Kole Čašule. Bratislava: Diliza, 1967).

Танески 2012: Звонко Танески, Проиесот на надградба во „словачката игра" на Коле Чашуле. Во: Македонско-словачки компаративни согледби (Звонко Танески). Скопје: Институт за македонска литература, стр 175-179.

Танески 2018: Звонко Танески, Научниот и преведувачкиот влог на Јан Јанкович во словачко-македонските книжевни и културни врски. Bo: Звонко Танески - Славистички синтези / Slavistické syntézy. Београд - Bratislava: Филолошки факултет - Универзитет у Београду / Asociácia organizácií spisovatel'ov Slovenska.

$$
* * *
$$

Čašule 1967: Kole Čašule: Hra na manželstvo. Veselohra zo súčasného života v dvoch častiach a 7 obrazoch (Игра или социјалистичка Ева). Preklad: Emil Horák. Bratislava: Diliza.

Čašule 1982: Kole Čašule, Čierňavy (Црнила). Dráma v štyroch častiach. Preklad: František Lipka. Nový Sad: Obzor (Ed. Nový život, zv. 1).

Čašule 1982a: Kole Čašule, Čierňavy (prvá čast'). Preklad: František Lipka. In. Nový život, č. 1, Roč. 34.

Čašule 1982b: Kole Čašule, Čierňavy (druhá čast'). Preklad: František Lipka. In. Nový život, č. 2, Roč. 34.

Čašule 1982c: Kole Čašule, Čierňavy (tretia čast'). Preklad: František Lipka. In. Nový život, č. 3, Roč. 34.

Čašule 1982d: Kole Čašule, Čierňavy (štvrtá čast'). Preklad: František Lipka. In. Nový život, č. 4, Roč. 34.

Čašule 1985: Kole Čašule, Úvodný prejav na deviatom zjazde zväzu spisovatel'ov Juhoslávie (Tento text vtedajšieho predsedu Predsedníctva Zväzu spisovatel'ov Juhoslávie Koleho Čašulu bol úvodným prejavom na 9. zjazde ZSJ 17. apríla v Novom Sade). Preklad: L'udmila Demáková a Miroslav Demák. In. Nový život, č. 5, Roč. 37, s. 343-358. 
Čašule 1987: Kole Čašule, Heslo. In. Encyklopédia spisovatel'ov sveta. Bratislava: Obzor, Spracoval kolektív autorov. Zostavovatel': Ján Jiríček. Heslo pripravili: Branislav Choma a Zlatko Klátik.

Čašule 1989: Kole Čašule: Tmy. In. Encyklopédia literárnych diel. Bratislava: Obzor, Spracoval kolektív autorov. Zostavovatel': Libor Kněžek. Autor textu: Ján Jankovič.

Čašule 2003: Kole Čašule, Heslo o autorovi. In. Encyklopaedia Beliana. Zväzok 3. Bratislava: Encyklopedický ústav SAV - Veda, vydavatel'stvo SAV, 2003.

Hronec 1982: Vít’azoslav Hronec, Bio-bibliografická poznámka o tvorbe Kole Čašuleho. In. Nový život, č. 4, Roč. 34.

Lipka 1982: František Lipka, Poznámka o autorovi-K. Čašule. In. Kole Čašule: Čierňavy - Dráma v štyroch častiach. Nový Sad: Obzor.

Lipka 1982a: František Lipka, Poznámka o tomto vydaní. In. Kole Čašule: Čierňavy (prvá čast'). Preklad: František Lipka. In. Nový život, č. 1, Roč. 34.

Staček 1973: L'ubomír Staček, : Mladost'-záruka kvality (Činohra Macedónskeho divadla v Bratislave). In. Práca, Roč. 28, 26. 9. 1973.

Taneski 2009: Zvonko Taneski, Slovensko-macedónske literárne a kultúrne vztahy. Bratislava: Juga / ústav svetovej literatúry SAV, s. 131-142.

Taneski 2020: Zvonko Taneski, Macedónska dráma na Slovensku po roku 1989. In. Slovenské divadlo (Revue dramatických umení). Bratislava: Ústav divadelnej a filmovej vedy SAV, 2020, č. 2, Roč. 68, s. 176-184.

Vrbacký 1948: Andrej Vrbacký, Nová macedónska literatúra. In. Národná obroda, č. 84, Roč. 4, Nedel'a - 11. apríla 1948.

Vrbacký 1973: Andrej Vrbacký, Macedónska hra na Novej scéne v pôvodine. Kole Čašule a jeho hra / Crnila-Kole Čašule. In. Ĺud, č. 228, Roč. 26, 25. 9. 1973, Rec.: Crnila / Kole Čašule (Divadelná inscenácia).

Zvonko Taneski

\section{DRAMA FROM THE MACEDONIAN WRITER KOLE CASHULE IN SLOVAK CULTURAL RECEPTION}

\section{Summary}

The article offers a complex overview of the presence of the dramatic literary works by the famous Macedonian author Kole Čašule in the Slovak Republic on the occasion of the 100th anniversary of his birth, which we fondly remember in the current 2021 . The author of the text conducted an archival research from which readers can get a complete 
picture of the overall reception of the works of this representative Macedonian writer in the Slovak cultural space (translations in periodicals and book editions). He also makes a more detailed analysis of the play Game or Socialist Eve, which appeared in a Slovak translation almost half a century ago.

Key words: Kole Čašule, Macedonian literature, Slovak reception, translation. 